\title{
Ideo-Cultural and Lexical Challenges Encountered in Translating Qur'anic Metaphoric Expression into English: With Reference to Three Translations of the Meaning of the Holy Quran
}

\author{
Dr.Ali Albashir Mohammed Alhaj Dr.Mesfer Ahmed Mesfer Alwadai \\ King Khalid University
}

\begin{abstract}
The current study aims to investigate the possible inconsistencies and incongruities that exist in the translation of metaphoric expressions of Qur'anic verses in the English. The analysis has been conducted through the comparison of prominent English translators of Quran such as Mohammed A.S Abdel Haleem, Mohammed. M Pickthall and Mohammed Khan and Mohammed Taj Al-Din Al-Hilal. Also, the study aims to explore how the three translators deal with the metaphoric expressions in their renditions of the Holy Quran. This endeavor is crucial for a comprehensive understanding of English translations of the Quran, particularly in the context of English readers for non-Arabic Muslims in particular, where euphemisms are concerned. The primary purpose of the present study is to examine the extent to which the three translators are accurate in translating the Qur'anic metaphors into English based upon the contexts and the interpretive meaning. It is hypothesized in this paper that Qu'ranic metaphors are rhetorical, aesthetic devices, but have unfortunately remained unattended by the majority of Holy Quran translators. The study has revealed that metaphors are used profusely throughout the Holy Quran, although translating these metaphors accurately is a difficult process owing to cultural and linguistic barriers that exist between Arabic and English cultures. It is expected that the study will cast light on two important ideas. The first is that the translators are fully aware of the existence of metaphoric expressions in the Qur'an. Secondly, it is essential that translators of the Holy Qur'an must translate these metaphors accurately to preserve the original meaning of the Qur'anic text.
\end{abstract}

Keywords: Qur'anic metaphors, linguitic, the metaphoric expressions, analysis, comparison, translating, and problems

DOI: $10.7176 / J L L L / 53-07$

\section{INTRODUCTION}

It is commonly assumed that the translators of the Holy Quran encounter many cultural and lexical problems and constraints in rendering this Holy Book. These problems emerge when the translators discover that there are some expressions in the Qur'anic text that is virtually untranslatable. It is observed that different versions of Qur'anic translations lead to different levels of comprehension and understanding on the part of the lay reader, especially when metaphoric expressions are considered.

The Holy Quran is rich in metaphoric expressions on various sensitive issues and topics such as sex, divorce, death and so on that need to be translated and examined. Sacredness and beauty of the Holy Quran make translation of the Qur'anic euphemisms problematic and challenging for the translators. To convey the Islamic values and beliefs accurately, the translator is forced to use different strategies such as paraphrasing, partial equivalents, literal translation, functional translation, among other techniques to address the challenge of correctly translating Qur'anic euphemisms.

There is a common belief that the translations of the Holy Quran can never achieve the same semantic and linguistic value that the original version of text contains. This problem arises for the following reasons:

a. English and Arabic are never sufficiently similar to express the same realities.

b. The Arabic language is richer not only in vocabulary but also in meaning, for example, metaphor is an obvious semantic problem that translators usually encounter when translating the text of the Holy Quran into English.

c. The beautiful and eloquent style of the Holy Quran.(In Arabic)

d. Metaphoric meanings of words.

e. The lack of equivalence at word levels.

\subsection{Research Questions}

To meet the issues mentioned above the following research questions are raised to find out to what extent:

1. does metaphor constitute one of the main components of translating the Holy Qur'an?

2. does metaphor offer one of the most effective parameters according to which both the literary competence of the translator and religious cultural awareness of the reader of the translation of the Holy Qur'an are revealed and gauged? 
3. do the three translators adopt strategies to ensure the preservation of original meaning in the translated text and the Arabic socio-cultural contexts and compensate for the loss of meaning in translation?

\subsection{Research Hypotheses}

1. Metaphor constitutes one of the main components of translating the Holy Qur'an?

2. Metaphor offers one of the most effective parameters according to which both the literary competence of the translator and religious cultural awareness of the reader of the translation of the Holy Qur'an are revealed and gauged?

3.The three translators adopt strategies to ensure the preservation of original meaning in the translated text and the Arabic socio-cultural contexts and compensate for the loss of meaning in translation

\section{RELATED LITERATURE}

\subsection{The Concept of Translation}

Translation is a process of transferring the theme or subject from one language, (Source Language, SL) to another language (Target Language. TL). In other words, it can be stated that through translation, the idea or thought expressed in one language is represented without deviation and distortion in another language. Translation is recognized as a device for overcoming the various linguistic and cultural and that, throughout history, have made such exchanges so complicated. Translating across languages and cultures enhancing the interactive dimension and facilities the search for and invention of new lexicons to develop the meaning of the receptor language in a new signifying context.

Translation is defined by scholars in many ways. Kusmaul (1995) considers it as a process and a product. Translation as a process is the way and methods of translating a text and as a product are how the translated text must be and what the translator produces. Catford (1990) also regards translation as a process which is derived from one direction, from the source to the target language. For him, translation is "the replacement of textual material in one language (SL) by equivalent textual material in another language (TL)" p.,14) The textual material in this definition means that the source text is not entirely translated but it is substituted by the TL equivalent. This definition shows that Catford focuses on the translation of text. He says that translation is an operation of replacing a text in one language by another language.

The act of translation is concerned with relation between the two languages viz., language from which translated and language into which the translation is affected. Ensuring equivalence between the two versions is an essential requisite for good translation. Incidentally, it may not be out of place to mention that translation generally refers to establishing relations between two different languages. However, the case of relating different dialectal forms of the same language cannot be ruled as a kind of translation in itself.

(Catford,1990,p.1) also sees translation as "an operation performed on languages : a process of substituting a text in one language for a text in another". The reference to "substitution" in this definition is important. According to him we do not" transfer" meaning between languages; we merely" replace a source language meaning by a target language meaning that can function in the same way in the situation at hand. This is achieved either through formal correspondence or through textual equivalence.

The theme and idea included in Catfrod's definition of translation denotes that what a translator may do, is to substitute possible equivalents and neither more or less than this: nevertheless, in the Qur'anic translation one word substitution is not possible.(, Hosni 2004, p 15).

The translations of the Holy Quran in English are usually confined to literal or word-for-word substitution. The translators might not have analyzed both Source Language (SL) and Target Language(TL) in their linguistic and non-linguistic contexts, hence, the receptor of the Message is, after all, frustrated in a state of confusion in comprehension of the translated text of the Holy Quran.

The English word translation has been derived from the Latin word translation, which itself comes from trans- and latum - together meaning "a carrying across" or "a bringing across(Cohen, 1986, ,p. 12)). In other words, it is the business of carrying across a message/written content from one text to another, from one person to another and from one language(source language) to a different language (target language). It can happen within the same language (from one dialect to another dialect or from one form to another) or between languages. It is best seen as a communication process where the transfer of a message/written content from one language into a new language takes place. (ibid,p.14)

In due course it may not be out of place to consider the definitions of translation provided by various scholars .

According to (Blight ,1976,p.12): The English word translation has been derived from the Latin word translation, which itself comes from trans- and latum - together meaning "a carrying across" or "a bringing across. In other words, it is the business of carrying across a message/written content from one text to another, from one person to another and from one language(source language) to a different language (target language). It can happen within the same language (from one dialect to another dialect or from one form to another) or 
between languages. It is best seen as a communication process where the transfer of a message/written content from one language into a new language takes place.

Translation is the general term refer to the transfer of thoughts and ideas from one language SL to another TL, whether the languages are in written or oral form, whether the languages have established orthographies or do not have such standardization or whether one or both languages is based on signs, as with sign languages of the deaf.

Translation can be defined as :"The placement of textual material in one language by equivalent textual material in another language". (Catford,1990,p.78)

This definition vaguely refers to the textual material. It does not, however, clearly indicate as to whether the significance is more on the meaning or style or the linguistic elements like the words and sentence structures. Catford's work" A Linguistic Theory of Translation( LTT)" (p.7) primarily focuses around various processes of translation with special emphasis on the linguistic elements like phonetic, phonological, grammatical and lexical, graphalogical and other kinds of translation like complete vs. partial, total vs. restricted and the like. He also deals about transliteration. The argument of Catford cannot be underestimated, but the point of concern is that the outlook of Catford is very restricted and narrow and does not satisfactory fulfill the requirements of translation. More important in the process of translation in the conveying of message from one language to the other and the linguistic equivalence is secondary to the thematic equivalence. According to Newmark (1998, p.45):

Translation is such an art wherein the message conveyed through one language is replaced by the same message in the other language.

The examination of various definitions leads us to conclude that translation is such an art whereby the message in the text in one language is transferred into the text of another language. The limitations and constrains involved in the process of translation are of serious concern.

( Halliday,1994,p.34), on the other hand, considers translation as "the relation between the text in the two languages involved,". According to him, the texts accomplish the same task under the same circumstances through the two different languages. He has no doubt aptly emphasized upon the significance of meaning. The aspects emerge out of a detailed examination of the viewpoints of various scholars of translation:

$>$ Translation is a linguistic exercise that takes place between two languages.

$>$ The language of the original text is called the source language and the language into which the translation is made is called the target language.

- The text in the target language is called the translated text.

$>$ The process of transfer or re-establishment of the meaning from the source language into the target language is the essence of the art of translation.

$>$ The expression between the SL and TL become synonymous. In other words, they convey the same meaning without distortion.

$>$ Several aspects figure in the process of translation. They include the linguistic aspects, socio-cultural aspects and contextual aspects. A unique combination of all these aspects could result in a successful and meaningful translation.

- The sole aim of the translator is to successfully transfer the essence of the original text in the translated text.

Understanding of ' translation' could be considered in two contexts:
$>$ In an extended context and
$>$ In a restricted context.

Translation in the extended context is considered as the transfer of meaning in one symbolic constitution into the other symbolic constitution. "Symbolic constitution" refers to the structural nuances of the two languages. On the other hand, translation in the restricted sense is considered as the process that takes place between two languages. This primarily refers to the linguistic aspects and the applications of principles to the art of translation. In fact, translation becomes meaningful if any and only if it is considered both in the restricted sense as well as the extended sense. Translation is the process of replacing an original text, known as the source, with a substitute one, known as the target text.

The process is usually an interlingual translation (translation proper) in that the message in the source language text is rendered as a target text in a different language, and it is in this sense that we have referred to translation so far. But sometimes the term is also used to refer to an intralingual translation (rewording), a process whereby a text in one variety of the language is reworded into another. This would be the case where the message of a text in, say, Old English (OE) is reworded into a text in modern English, or a text in one dialect or style is reworded into another. And we can speak of 'translation' when the replacement involves not another language but another, non-linguistic, means of expression, in other words a different semiotic systems. In this sense we can say for instance that a poem is ' translated' into a dance or a picture, a novel into an operator a film. Such transmutations are examples of intersemiotic translation. (Jakobson, 1959/1990, p.232). What all these 
three processes have in common is that they involve the replacement of one expression of a message or unit of meaningful content by another in a different form.

The term 'translation' is also sometimes used to describe linguistic activities such as summarizing or paraphrasing. Although such activities resemble translation in that they replace a message that already exists, they differ in that they are designed not to reproduce the original as a whole but to reduce it to its essential parts, or adapt it for different groups of people with different needs and expectations.

The term "translation" is the mental term used for all tasks where the meaning of an expression in one language (the 'source' language) is turned into the meaning of another (the 'target' language), whether the medium is spoken, written or signaled. It is an operation performed on languages through the replacement of textual material in one language (source language) by equivalent textual material in another language (target language). By replacement of textual material, we mean a replacement of source language graphology, grammar and lexis by equivalent target language graphology, grammar and lexis. Source language (SL) means the form from which the translation is made and target Language/ receptor language (TL/RL) is the form into which the $\mathrm{SL}$ is to be changed. By equivalence we mean text in different languages can be equivalent in different degrees(fully/partially equivalent), in respect of different levels of presentation (equivalent in respect of context of semantics, grammar, and lexis ) and at different ranks (word-for-word, phrase-for-phrase, sentence-forsentence).Since meaning is central in translation, it will not be acceptable to say that translation only involves changing of form of the first language to the form of the second language. Translation consists of transferring the meaning of the SL into the TL which is done by going from the form of SL to the form of TL by way of semantic structure.

There have been a number of theories of translation that have been debated about. They include:

i. Linguistic Theory.

ii. Universalist Theory.

iii. Relativist Theory .

While Catford(1991) is the proponent and authority on the linguistic theory of translation, Steiner(1992) has proposed the universal and relativist theories. The theory of translation primarily deals with the linguistic aspects like the structural and lexical equivalences, formal correspondence, transference, transliteration, several types of translation like partial and total translation, phonological and graphalogical translation, translation shifts and the limits of translatability. (Kelly p.1997, p.60) as the name of the theory is indicative, the linguistic theory of translation is mostly concerned about the structure and less about the content/theme. Thus, the linguistic theory of translation fails to take care of the content aspect which is a serious setback to the art of translation. The reason is that the primary purpose of translation is to convey the content/theme from one language to the other without loss or distortion of the theme in the source language; thereby the significance of the thematic accuracy over-rides the linguistic accuracy. There is no exaggeration if it is argued that the linguistic accuracy in translation plays a secondary role. However, the linguistic aspects should not be made insignificant. It means that while utmost importance is given to the thematic accuracy, linguistic accuracy and correspondence between the SL and TL need to be maintained to the maximum possible extent. It follows that a good translation necessitates an ideal integration of the thematic transfer and linguistic transfer from the SL to TL. (Kelly, p.1997, p.61)

The Universalist theory according to Hewson and Martin is based on an extension of the economic concept of contractual transaction. (Kelly, p.1997, p.68) .The term 'contract' refers to the act of translation. The term 'transaction' refers to the act of conciliation between the two languages and the unification established between them by the process of translation.( By unification is meant the establishment of one to one correspondence between SL text and the TL text not merely from the linguistic aspect but from the thematic aspect as well. According to Martin and Mason (1997,p.45):

Translation, as a particular form of contract, is an agreement between the two LC is involved to transfer signification on a common convertibility basis in so far it is not detrimental to the specific differences between cultures. The fundamental notion both on the economic and on the translational planes is compromise; i.e., the agreement to remain separate in order to achieve a common goal.

A good translation or an ideal contract is possible within the scope of a single culture. Therefore, the Universalist conversion envisages the relationship between cultures as possible. But, necessarily, such relationship is only partial or flawed.( Cohen.1990,p.34). Some scholars, however, argue that in spite of diversity of cultures, there exists reasonable quantum of universals based on which the transaction or translation could be considered as reasonable and sufficient though the transaction/ translation excludes the total correspondence or one to one correspondence. They agree that the transfer of the deeper and wider interpretations between the two cultures gets precluded. (Cohen.1990, p.36)

In believing that cultural relationships are contractual transactions, translation can be conceived of as a process of transference based on the criterion of equivalence. Practically, this view boils down to the argument that a sound and reasonablecompromise between the structural and thematic equivalences has to be ensured in good translation. Departing a little bit from this view, scholars like Hewson and Martin have preferred to argue 
that transference is necessarily partial and therefore, translation necessarily involves some loss. They, however, give a word of caution that this possible loss should be kept to the minimum and to the extent possible; it is to be compensated with the normalization of the common core. They conclude that translation consists in constantly perfecting the fundamentally uncontestable compromise.(Devey,1990,p.77).

The relativist theory is concerned with the concept of production within an interactive structure. From this point of view, common core or the universals are not only compressive as non-existence, but they contribute to "denaturing" of communication. The most important aspect in the art of translation is that the essential of signification lies in particulars and differences which can never be Universalist any way, but only exist in proportion to their specificity. It follows that signification can never be repealed, duplicated or transferred; it can only be reformulated and adapted to the ever changing conditions of meaning definition. The point to be taken note of in this context is that "meaning" is the most significant aspect in the art of translation. The act of producing the meaning intact in the language translated into besides the alterations in the factors involved in communication i.e., the medium or language adopted is essential. It is for this reason that constant adaptation is extremely significant and important in the context of translation. (Cohen.1990,p.67)

As stated above, perfect integration and correlation between the structure and content, expression and reality needs to be ensured which is associated with the concept of signification in the context of translation. Drawing the attention to these factors, Steiner (1992, p.89) argues that;

The role of translation is determining in this process of cultural cross determination, since in translation the dialectic of unison and plurality is dramatically at work

Martin and Mason (1997)call this process as "hermeneutic". Meschonnic conceives of translation as a unique combination of "rapport and tension". While rapport refers to a close correspondence between the SL and TL expressions, "tension" refers to the idiosyncrasies particularly in the context of aspects relating to culture. These aspects could be taken care of suitably to make the translation as perfect as possible only through exemplification and explanations of typical and unique cultural and social aspects etc. The exemplifications and explanations so required are called "complexification of perspective" Martin and Mason (1997, p.38).

\section{Research Approach}

In the current study, the researcher used descriptive qualitative methods. Secondly, text analysis design was used to find metaphoric expressions in the English translation of the meanings of the Holy Quran. The Qur'anic translations explored in the study are:

(i) Mohammed A.S Abdel Haleem (2005) (a native Arabic speaker),

(ii) Mohammed M.Pickhall (1997) (a native English speaker)

(iii) Mohammed Muhsin Khan and Mhammed Taqi Al-Din Al-Hilali (1996) (a native speaker of neither Arabic nor English).

\subsection{Data Collection Procedure}

The current research aims at describing, analyzing and evaluating the principles, methods, and procedures of translating the text of the Holy Quran, and particularly, explaining the problems of translating metaphoric expressions in the three selected translations of the Holy Quran. The objective of the current research is the establishment of the basic and secondary meaning of e metaphoric xpressions and their derivations in the translation of the meaning of Holy Quran.

The most vital and crucial research instrument is reading, analyzing and comparing the translated text of selected Surrah by the three different translators. This study is an eclectic study where three popular translations of the Holy Qur'an have been analyzed and identified as the different kinds of translation, i.e., semantic translation, communicative translation, etc. When analyzing the three translations, the researcher followed the following procedures:

a. quoting the Arabic versions of Quranic ayat in which metaphoric expressions under investigation occur, enumerating metaphoric expressions in both versions Arabic and English, and then putting the three translations of the same ayah into a table directly under each one of the three translators.

b. Studying metaphoric expressions in terms of the problems of meaning and textual problems based on (strong/mid/weak) connotation.

c. Analyzing metaphoric expressions aspects of meaning focusing on some selected ayahs in which metaphoric expressions appear in the Holy Quran, here the researcher chooses some examples for the context particularly in which either metaphoric expressions appear.

d. Analyzing Abdel-Haleem, Khan and Hilali and Pickthal's translations and identifying their accuracy, effectiveness, and then giving comments on the three translations.

\section{RESULTS AND DISCUSSIONS}

Regarding the analysis of the collected data, some Quranic have been selected by the researcher. The selected 
ayahs contain some metaphoric expressions. The analysis of the of the data was carried out by utilizing comprehensive tables displaying: SL texts, TL text, meaning, types of methods, Furthermore, the analysis of the data has been devoted to metaphoric expressions and the way each selected translator used them. However, all ayahs have not been analyzed in this thesis due to the limitations of the current study. Then, only the translations that appear give different meanings from what has established have been explored. Finally, in case of having an effective rendering, which coincides with the religious interpretation, it will be chosen as a proposed rendering; otherwise, a new rendering will be suggested.

\subsection{Examples of Metaphoric Expressions in the Holy Quran Translations} Example 1

( المائدة: 63 (

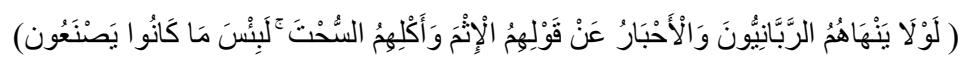

Lawla yanhahumu alrrabbaniyyoona waalahb $\underline{\text { aru AAan }}$ qawlihimu alithma waaklihimu alssuhta labisa ma kanoo yasnaAAoona.

The triliteral root sīn ḥā tā $(\omega)$ ) occurs in $\mathbf{2}$ Surahs and appears 4 times in the Qur'an, in 2 derived forms.

\begin{tabular}{|c|c|c|c|}
\hline ST(metaphor) & $\begin{array}{c}\mathrm{T} 1 \\
\text { Abdel-Haleem }\end{array}$ & $\begin{array}{c}\text { T2 } \\
\text { Khan and Hilali }\end{array}$ & $\begin{array}{c}\text { T3 } \\
\text { Pickthall }\end{array}$ \\
\hline 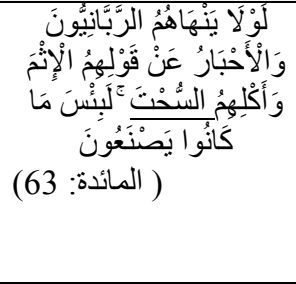 & $\begin{array}{l}\text { Why do their rabbis and } \\
\text { scholars not forbid them } \\
\text { to speak sinfully and } \\
\text { consume what is } \\
\text { unlawful? How evil } \\
\text { their deeds are! }\end{array}$ & $\begin{array}{l}\text { Why do not the rabbis and the } \\
\text { religious learned men forbid } \\
\text { them from uttering sinful words } \\
\text { and from eating illegal things. } \\
\text { Evil indeed is that which they } \\
\text { have been performing. }\end{array}$ & $\begin{array}{l}\text { Why do not the rabbis and } \\
\text { the priests forbid their } \\
\text { evil-speaking and their } \\
\text { devouring of illicit gain? } \\
\text { Verily evil is their } \\
\text { handiwork. }\end{array}$ \\
\hline
\end{tabular}

\section{Discussions}

The meaning of this ayah is: had it been but that the Rabbaniyyun and the Ahbar forbid them from committing such evil acts The Rabbaniyyun are the religious learned men having the authority, "Evil indeed is that which they have been performing "in reference it is to their abstaining from forbidding of committing evils. It is to their abstaining from forbidding of committing evils. It is recorded that Ibn Ibbas said:"No verse in the Qur'an heaps reproaches than this verse:" Why do not the rabbis and the religious learned men forbid them"," Similar it is to what Adhahak said:" There is no verse in the Qur'an that I'm admonished there with than this verse. One upon a time, Ali Abi-Talib delivered a speech after praising Allah and thanking Him saying," O 'people ! What perished those who were before you was that they used to committed evils and the Rabbaniyyun and the Ahbar amongst them didn't forbid them against committing such evils. When they insisted on committing sins. They were seized with punishments. Therefore, enjoin righteousness and forbid evil before the like of what had fallen them strikes you and know that commanding what is righteous and forbidding what is evil does not cease provision nor does it shorten one's fixed term of life." It is narrated in the Hadith; "No people who have amongst them those who commit what is prohibited while they themselves are of more power and might than the sinners and they didn't stop them,but that they will be afficted with totutre from Allah"( narrated by Imam Ahmed)

In (Abdel-Haleem's rendition of the metaphoric expression 1-suh'ta السُحْتَ the metaphor " 1-suh'ta السُحْنَ " which is "_consume what is unlawful "and ignores the metaphoric expression " 1suh'ta السُحْتَ " whose meaning is less embarrassing than the meaning of bribe. Moreover, Khan and Hilali rendered the same metaphoric expression into"_eating illegal things" but their translation is literal and they have been used literal translation strategy to come up with exact or better meaning of the metaphor " 1-suh'ta السَُّْْتَ but

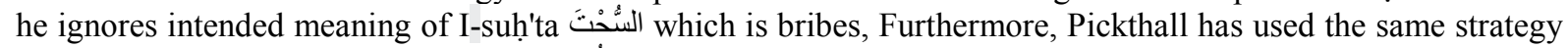
when translated the metaphor l-suh'ta السُحْتَ into English" devouring of illicit gain ". He also, ignores intended meaning of l-suh'ta السُحْنَ which is bribes.

However, the three translators' rendering for the metaphoric expression 1-suh'ta السُحْنَ in inappropriate because it does not convey the given meaning of" l-suh'ta السُّحتَتَ which is bribes and the receptor may be confused or frustrated. Moreover, Hilali and Khan used the translation explanation and addition strategies to render the lexeme more appropriately and accurately but their rendition does not convey the accurate meaning. Moreover, the three translators used the communicative method which hits high degree of translational coincidences with the interpretation in Khan and Hilali's renderings, but it hits average in Abdel-Haleem's and Pickthall's renderings. 


\begin{tabular}{|c|c|c|c|c|c|c|}
\hline Type & \multicolumn{3}{|c|}{ Semantic translation } & \multicolumn{3}{|c|}{ Communicative translation } \\
\hline No. of Translation & High & Average & Low & High & Average & Low \\
\hline T1consume what is unlawful & & & & & + & \\
\hline T2eating illegal things & + & & & & & \\
\hline T3devouring of illicit gain & & & & & + & \\
\hline
\end{tabular}

The three translators' rendered the ' the metaphoric expression l-suh'ta السُحْنَ to (consume what is unlawful, consume what is unlawful and devouring of illicit gain)respectively, which is not denotatively or connotatively equivalent to ( bribes), hence their translation has connotation.

\begin{tabular}{|c|l|l|c|}
\hline Method of translation & Strong connotation & Mild connotation & Weak connotation \\
\hline $\begin{array}{c}\operatorname{Tr}(1) \\
\text { literal }\end{array}$ & & & + \\
\hline $\begin{array}{c}\operatorname{Tr}(2 \\
\text { couplet }\end{array}$ & & & + \\
\hline $\begin{array}{c}\operatorname{Tr}(3) \\
\text { literal }\end{array}$ & & & + \\
\hline
\end{tabular}

\section{Example 2}

Laakhathna minhu bialyameeni

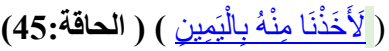

he triliteral root yā mīm nūn (ي م ن) occurs in 34 Surahs and appears 71 times in the Qur'an, in 2 derived forms

\begin{tabular}{|c|c|c|c|}
\hline ST(metaphor) & $\begin{array}{c}\text { T1 } \\
\text { Abdel-Haleem } \\
\end{array}$ & $\begin{array}{c}\mathrm{T} 2 \\
\text { Khan and Hilali }\end{array}$ & $\begin{array}{c}\text { T3 } \\
\text { Pickthall } \\
\end{array}$ \\
\hline 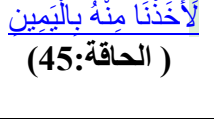 & $\begin{array}{l}\text { We would certainly have seized his } \\
\text { right hand }\end{array}$ & $\begin{array}{l}\text { We surely should have seized } \\
\text { him by his right hand (or with } \\
\text { power and might), }\end{array}$ & $\begin{array}{l}\text { We assuredly } \\
\text { had taken him by } \\
\text { the right hand }\end{array}$ \\
\hline
\end{tabular}

\section{Discussions:}

The meaning of this ayah is: " we would seize him by the right hand because it is more severer in

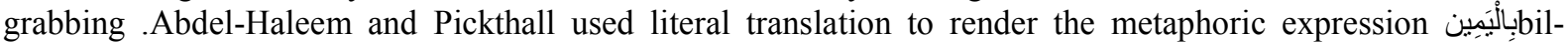
yamīni into " We would certainly have seized his right hand"," We assuredly had taken him by the right hand" respectively. Semotactically, Abdel-Haleem Khan and Hilali's rendering(seized his right hand) is ambiguous; hence, their rendition is inaccurate and inappropriate and unnatural to the receptor's expectations and definitely confusing, but, Khan and Hilali's rendering hence his rendition ranks the best, because they clarified the ambiguity by adding (with power and might). Also Hilali \& Khan combining their translation with an explanatory note, telling the receptors directly about the intended meaning of the text at hand(a translation method that combines two procedures to deal with a single problem "literal translation + explanation").

All the three translators used the Communicative translation which hits high degree of translational coincidences with the interpretation for translating render the metaphoric expression بإلَيَيَين would certainly have seized his right hand'.

\begin{tabular}{|l|c|c|c|c|c|c|}
\hline \multicolumn{1}{|c|}{ Type } & \multicolumn{3}{c|}{ Semantic translation } & \multicolumn{3}{c|}{ Communicative translation } \\
\hline \multicolumn{1}{|c|}{ No. of Translation } & High & Average & low & High & Average & Low \\
\hline T1seized his right hand & & & & + & & \\
\hline T2seized him by his right hand & & & & + & & \\
\hline T3taken him by the right hand & & & & + & & \\
\hline
\end{tabular}

All the three translators are adequate in rendering the intended connotative meaning the metaphoric

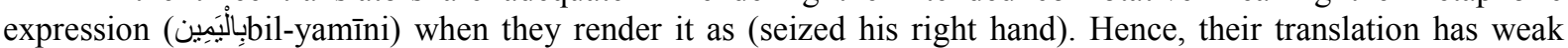
semantic connotation.

\begin{tabular}{|c|c|c|c|}
\hline Method of translation & Strong connotation & Mild connotation & Weak connotation \\
\hline $\begin{array}{ll}\operatorname{Tr}(1) & \\
& \text { literal } \\
\end{array}$ & & & + \\
\hline $\begin{array}{ll}\operatorname{Tr}(2) \quad \text { couplet } \\
\end{array}$ & & & + \\
\hline $\begin{array}{ll}\operatorname{Tr}(3) & \\
& \text { literal }\end{array}$ & & & + \\
\hline
\end{tabular}

To conclude, the tendency of the translators to reduce the ST informativity factor widens the gap among the textual cohesive links" which feeds into the overall textuality and textness of Quran discourse "(AbdulRaof,2004,160). The TT could be judged as not being as informative as required in particular the continuity of 
sense.

\section{Example 3}

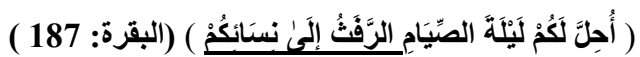

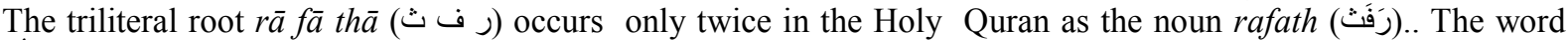

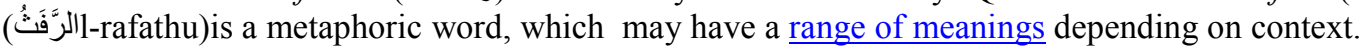

\begin{tabular}{|c|c|c|}
\hline 1. (2:187) l-rafathu & $\begin{array}{l}\text { (is) the } \\
\text { approach }\end{array}$ & 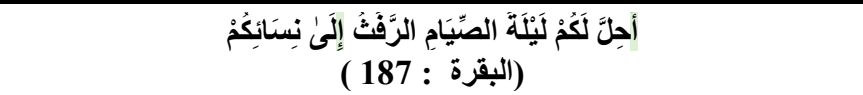 \\
\hline 2. (2:197) rafatha & sexual relations & 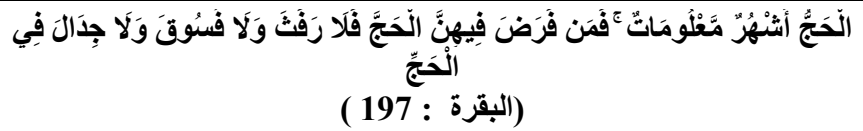 \\
\hline
\end{tabular}

\begin{tabular}{|c|c|c|c|}
\hline ST(metaphor) & $\begin{array}{c}\mathrm{T} 1 \\
\text { Abdel-Haleem }\end{array}$ & $\begin{array}{c}\text { T2 } \\
\text { Khan and Hilali }\end{array}$ & $\begin{array}{c}\text { T3 } \\
\text { Pickthall }\end{array}$ \\
\hline 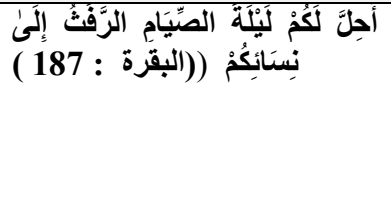 & $\begin{array}{l}\text { You }\{\text { believers }\} \text { are } \\
\text { permitted to lie with your } \\
\text { wives during the night of } \\
\text { the fast. }\end{array}$ & $\begin{array}{l}\text { It is made lawful for you } \\
\text { to have sexual relations } \\
\text { with your wives on the } \\
\text { night of As-Saum (the } \\
\text { fasts) }\end{array}$ & $\begin{array}{l}\text { It is made lawful for you } \\
\text { to go in unto your wives } \\
\text { on the night of the fast }\end{array}$ \\
\hline
\end{tabular}

\section{Discussions}

The meaning of this ayah is: (It is made lawful for you to have sexual relations with your wives on the night of As-Saum),Allah made it lawful for Muslims what was unlawful and hard to bear at the beginning of Islam when it was lawful for a Muslim to eat, drink and copulate only from the time he beaks his fast till the time of praying the 'Isha., and that if he slept or prayed the 'Isha prayer, it is forbidden for him then to eat or drink or copulate till the next set of the sun."( Tafsir Ibn Kathir volume. I,2007,p.108)

According to Al-Esfahani (1997,p.359) الرَّفَنُ sexual intercourse. It is a metonym for sexual intercourse. Considering the above translations, it can be noted that Abdel-Haleem rendered the metaphoric lexeme الرََّفَُ Hilali rendered the same lexeme into"_have sexual relations with your wives'. Therefore, they ignored the metaphoric expression which is used to reduce the direct meaning of sexual intercourse and mentioned only the interpretive meaning of (have sexual relations). Pikthal rendered the metaphoric lexeme الرََََُّْ go unto"; hence he did not translate the intended and the interpretive meanings of the lexeme. According to(Hosni, 2007,p.626 )

In this verse, the word [?arrafa]] ,i.e. going in unto wives' is a euphemism for the sex-act or copulation . Instead of the explicit mention of having sex with one's wife on the night of the fast, the word [?arrafä] is used so as to gloss over the down-to-earth direct expression of copulation. The context within which the word [Parrafat] occurs necessitates a sort of mollification. This, however, is due to the devotion of votaries who are supposed to go in unto their wives only after they break their fast. Breaking one's fast does occur only at dusk time and into the night. Only then are fast-breakers allowed to have intimacy with their wives. The whole

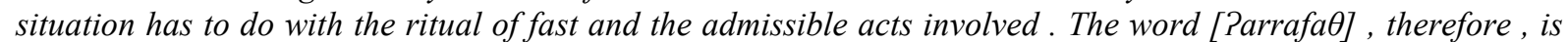
being used as a euphemism for "having sex with" or "copulating with" or "having sexual intercourse with" (one's wife), etc.

On their turn, Al- Zamakhshari( 1998,p.389) and Al-Baydawi(1999,p.10) agree that the word rafath (رَفَ) sounds more negative than some other expressions used as euphemisms for the same purpose such as afḍa ila

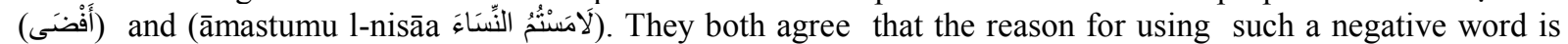
disapproval of the actions of some Sahābah who had sexual relations with their wives when it was prohibited.

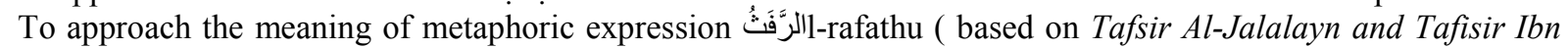
Kahir) in the ayah, Khan and Hilali as well as Abdel-Haleem used the semantic method which hits average degree of translational coincidences with the interpretation.However, Pickthal used Communicative method which hits low degree of translational coincidences with the interpretation.

\begin{tabular}{|c|c|c|c|c|c|c|}
\hline Type & \multicolumn{3}{|c|}{ Semantic translation } & \multicolumn{3}{c|}{ Communicative translation } \\
\hline No. of Translation & High & Average & Low & High & Average & Low \\
\hline T1)permitted to lie with your wives & & + & & & & \\
\hline T2)have sexual relations with your wives & & + & & & & \\
\hline T3)to go in unto your wives & & & & & & + \\
\hline
\end{tabular}

Khan and Hilali's rendition is semantic translation producing an exposed sort of euphemism by using the expression "sexual relations". Hence, their rendering has mild connotation In other words, using the word 
'relation' in Khan and Hilali's rendition, it is obvious that the two translators have attempted to produce a metaphoric translation However, studies failed to produce evidence that the phrase' sexual relations' can be

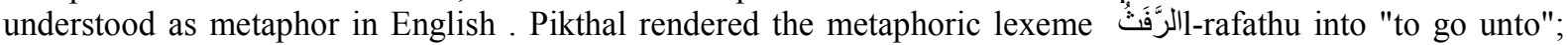
hence he did not convey metaphoric meanings of the lexeme, hence his rendition has weak connotation. But, Abdel-Haleem rendered the metaphoric lexeme الرَّفَثُ

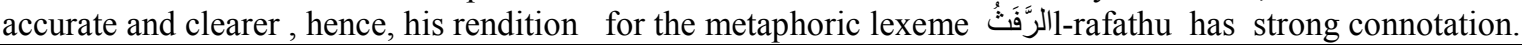

\begin{tabular}{|c|c|c|c|}
\hline Method of Translation & Strong connotation & Mild connotation & Weak connotation \\
\hline T1 & + & & \\
\hline Semantic method & + & & \\
Semantic method & & & + \\
\hline T3 & & & \\
\hline
\end{tabular}

To conclude that, metaphor has come to be realized not only as a matter of language, but also as an important aspect of cognition. Thus, according to cognitive linguists, metaphor is not merely a figure of speech; it is also a way of thinking and conceptualizing

\section{Example 4}

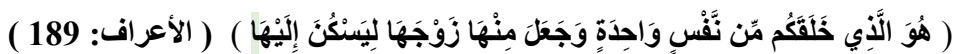

The triliteral root sīn kāfnū( س ك ن ن ) occurs in 40 Surahs and appears 69 times in the Qur'an, in 6 derived forms. The translations below are brief glosses intended as a guide to meaning. The word' لَِيَنْكُنَ liyaskuna may have a range of meanings depending on context.

\begin{tabular}{|c|c|c|c|}
\hline $\begin{array}{c}\text { ST } \\
\text { (metaphor) }\end{array}$ & $\begin{array}{c}\mathrm{T} 1 \\
\text { Abdel-Haleem }\end{array}$ & $\begin{array}{c}\mathrm{T} 2 \\
\text { Khan and Hilali }\end{array}$ & $\begin{array}{c}\text { T3 } \\
\text { Pickthall }\end{array}$ \\
\hline 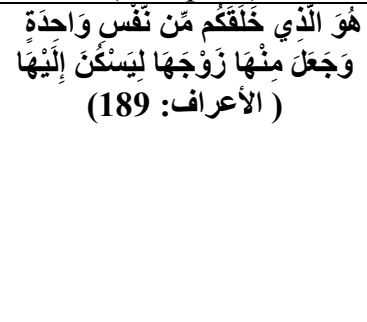 & $\begin{array}{l}\text { It is who created you all } \\
\text { from one soul, and from it } \\
\text { made its mate so that he } \\
\text { might find comfort in her }\end{array}$ & $\begin{array}{l}\text { It is He Who has created } \\
\text { you from a single person } \\
\text { (Adam), and (then) He } \\
\text { has created from him his } \\
\text { wife [Hawwa (Eve)], in } \\
\text { order that he might enjoy } \\
\text { the pleasure of living with } \\
\text { her }\end{array}$ & $\begin{array}{l}\text { He it is Who did create } \\
\text { you from a single soul, } \\
\text { and therefrom did make } \\
\text { his mate that he might } \\
\text { take rest in her }\end{array}$ \\
\hline
\end{tabular}

\section{Discussions}

In the above ayah, the word 'لِيَنْكُنَ liyaskuna (lit that he might live.) in expressions like 'liyaskuna ilayha لَيسنكُنَ ' إََْْهَا between husband and wife or couples since they are described as one soul (Al-Tabari, 2000,). This ayayh in was contextually revealed to remind humans of Allah's signs among which are that He created them from a single soul, namely, Adam, and made his spouse, Eve, out of him. The purpose behind this creation is that Adam might live in ultimate peace with his wife through being intimate with her and to bring offspring as a result.

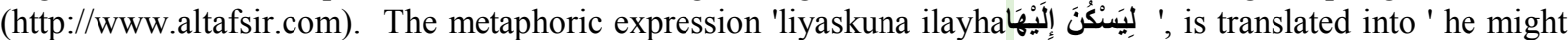
enjoy the pleasure of living with her by Khan and Hilali, and such a literal translation is more general and convey non-sexual connotation because the phrase ' enjoy the pleasure ' has never been used to express any sexrelated meaning (Rawson, 1981,). Further, " enjoy the pleasure" does not even convey the general meaning of the said expression' 'liyaskuna ilayha' in the ST which entails the ultimate level of living in peace and satisfaction with a wife (Qutb, 2003, p.37). In contrast, the ST is transferred into 'he might rest in her' by Pickthall and this expression is also more general and, as metaphor, is more associated with "the relaxation that is obtained through death, as in eternal rest, called to heavenly rest, go to rest, and laid to rest " (Rawson, 1981, p.236). As for Abdel-Haleem, the ST is rendered into a more illustrative, accurate and clearer expression He might find comfort in her ", which indicates the translator's awareness of the ST intention.. The use of 'comfort in her' as equivalence to ' liyaskuna ilayha' is a real success since 'comfort' is metaphoric expression for intimate copulation especially when sought by a male (Holder, 2008, p.1)

To approach the meaning of metaphoric expression is' لِيَنْكُنَ liyaskuna ( ( based on Tafsir Al-Jalalayn and Tafisir Ibn Kahir) in the ayah, Abdel-Haleem used the semantic method which hits high degree of translational coincidences with the interpretation. Khan and Hilali used communicative method which hits average degree of translational coincidence with the interpretation, whereas Pickthall used the same method which hits low degree of translational coincidence with the interpretation, 


\begin{tabular}{|l|c|c|c|c|c|c|}
\hline \multicolumn{1}{|c|}{ Type } & \multicolumn{3}{c|}{ Semantic translation } & \multicolumn{3}{c|}{ Communicative translation } \\
\hline \multicolumn{1}{|c|}{ No. of Translation } & High & Average & low & High & Average & Low \\
\hline T 1)he might find comfort in her & + & & & & & \\
\hline T 2) might enjoy the pleasure of living with her & & & & & + & \\
\hline T3) he might take rest in her & & & & & & + \\
\hline
\end{tabular}

Abdel-Haleem is adequate in rendering the intended connotative and euphuistic meaning لِِنَنْكَن liyaskuna when he renders it as (find comfort in her). Hence, his translation has strong convocation. Unfortunately, Khan and Hilali as well as Pickthall's renditions for the same connotative and metaphoric meaning are inaccurate and out of context. Hence, their translations have weak connotation.

\begin{tabular}{|l|c|c|c|}
\hline \multicolumn{1}{|c|}{ Type of translation } & Strong connotation & Mild connotation & Weak connotation \\
\hline $\operatorname{Tr}(1)$ semantic translation & + & & \\
\hline $\operatorname{Tr}(2)$ literal translation & & & + \\
\hline $\operatorname{Tr}(3$ literal translation & & & + \\
\hline
\end{tabular}

\section{Example 5}

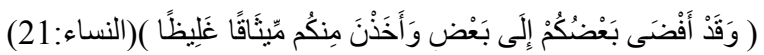

The triliteral root fā ḍād wāw (ف ض ض و occurs in 1 Surah and appears 1 time in the Qur'an, in 1 derived form., as

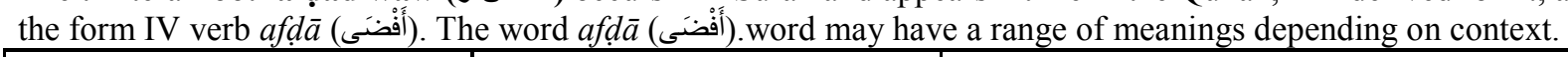

\begin{tabular}{|c|c|c|}
\hline (4:21:4) af $\bar{a} \bar{a}$ & has gone & وَفَفْ أَفْضَى بَعْضُكُمُ إلَّى بَعْضٍ \\
\hline
\end{tabular}

\begin{tabular}{|c|c|c|c|}
\hline ST( metaphor) & $\begin{array}{c}\text { T1 } \\
\text { Abdel-Haleem }\end{array}$ & $\begin{array}{c}\text { T2 } \\
\text { Khan and Hilali }\end{array}$ & $\begin{array}{c}\text { T3 } \\
\text { Pickthall }\end{array}$ \\
\hline 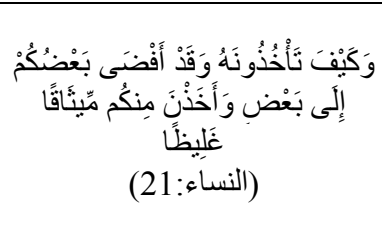 & $\begin{array}{l}\text { How could you take it } \\
\text { when you have lain with } \\
\text { each other and they have } \\
\text { taken a solemn pledge } \\
\text { from you? }\end{array}$ & $\begin{array}{l}\text { And how could you take } \\
\text { it (back) while you have } \\
\text { gone in unto each other, } \\
\text { and they have taken from } \\
\text { you a firm and strong } \\
\text { covenant? }\end{array}$ & $\begin{array}{l}\text { How can ye take it (back) } \\
\text { after one of you hath gone } \\
\text { in unto the other, and they } \\
\text { have taken a strong } \\
\text { pledge from you?: }\end{array}$ \\
\hline
\end{tabular}

\section{Discussions}

"How can ye take it (back) after one of you hath gone in unto the other, and they have taken a strong pledge from you ?" (Pickthall). And how could you take it (back) while you have gone in unto each other) how can you take back the dowry from the woman with whom you had sexual relations and she had sexual relations with you Ibn `Abbas, Mujahid, As-Suddi and several others said that this means sexual intercourse. (And how could you take it (back) while you have gone in unto each other and they have taken from you a firm and strong covenant) (Be kind with women, for you have taken them by Allah's covenant and earned the right to have sexual relations with them by Allah's Word.). In this example the metaphor was translated perfectly into English

This verse tackles a significant matter that has to do with the husband's commitment to the rituals of marriage . It is incumbent upon him to live up to the promise he had made to be noble and chivalrous . This means that there is a knot of matrimony being effected and a dowry is paid out to the bride, and this already paid dowry should not be taken back in the wake of the consummation (of marriage). This, in matter of fact, is an admonition addressed to the husband so as to act on it and never to overstep his limits . In other words, when the husband consummates the marriage, he has no right

Literal translation of some words, idioms and fixed expressions in the Quran fails to render the intended meaning of the original ones clearly into English. This is because in some cases, the translators, especially Arberry, render only the denotative meanings of these linguistic features. They transfer them as they were found in the dictionary. Since the connotative meaning of a word in Arabic is often not the same as that of an English word almost having almost the same denotative meaning, the literally rendered meaning neither transfers the genuine meaning nor does it match the general content of the text. The words are English but they do not relay an obvious message. Consequently, the reader fails to grasp the meaning. Dickins et al. (2002: 97) warn that "in translation, lexical loss is very common, and this arises from the fact that exact synonymy between ST words and TT words, is relatively rare". They (ibid) add that "meanings are not found exclusively in the words listed individually in the dictionary". Lexical loss then results in a text that lacks clear meaning, badly affecting intelligibility.

The 'firm covenant' in this verse refers to marriage. For marriage is a firm covenant of fidelity. It is only because a woman has faith in the firmness of this covenant that she entrusts herself to a man. If a man decides of his own will to break it, he has no right to withdraw the amount he offered his wife by way of bridal-due at the 
time of entering into that covenant. (See Towards Understanding the Qur'an, vol. I, Surah 2, n. 251.)

All the three translators used the communicative method which hits high degree of translational coincidences with the interpretation in Khan and Hilali's renderings, but it hits average in Abdel-Haleem's and Pickthall's renderings.

\begin{tabular}{|l|c|c|c|c|c|c|}
\hline \multicolumn{1}{|c|}{ Type } & \multicolumn{3}{c|}{ Semantic translation } & \multicolumn{3}{c|}{ Communicative translation } \\
\hline \multicolumn{1}{|c|}{ No. of Translation } & High & Average & Low & High & Average & Low \\
\hline T1)permitted to lie with your wives & & & & & + & \\
\hline T2) have sexual relations with your wives & & & & + & & \\
\hline T3) to go in unto your wives & & & & & + & + \\
\hline
\end{tabular}

All the translators failed to transfer the euphemistic nature of . To solve this problem they should have used the metaphor plus a paraphrase or an annotation. SL Text.Hence their translation has weak connotation.

\begin{tabular}{|c|c|c|c|}
\hline Type of translation & Strong connotation & Mild connotation & Weak connotation \\
\hline $\operatorname{Tr}($ 1)literal translation & & & + \\
\hline $\operatorname{Tr}(2)$ literal translation & & & + \\
\hline $\operatorname{Tr}(3$ literal translation & & & + \\
\hline
\end{tabular}

\subsubsection{Verification and Testing of the Study Hypotheses:}

\section{Hypothesis One:}

Hypothesis (1) is stated as follows:

Metaphoric constitutes one of the main components of translating the Holy Qur'an.

This hypothesis addresses Research question which aims to find out to what extent metaphor constitutes as one of the main components of translating the Holy Qur'an into English. The analysis of the verses proved that translator has to deal with quite distinctive cultures with temporal and spatial differences in rendering metaphor into English. Also the translator has to face multifarious difficulties of rendering metaphor through a balanced approach .For example, the translator will essentially provide all inevitable introductory knowledge about Qura'nic metaphoric and its style.

\section{Hypothesis Two:}

Hypothesis (2) is stated as follows:

Metaphoric offers one of the most effective parameters according to which both the literary competence of the translator and religious cultural awareness of the reader of the translation of the Holy Qur'an are revealed and gauged.

This hypothesis arises from Research Question(2) which aims to find out to what extent metaphor offers one of the most effective parameters according to which both the literary competence of the translator and religious cultural awareness of the reader of the translation of the Holy Qur'an are revealed and gauged.

metaphor involves the semantic structure of both individual words and texts. It, therefore, deals with complex semantic relations working at the level of microsemantics, and it is for this reason, strongly related to literary in general and religious text in particular. metaphor in words, expressions and texts expounds both the expressive and the emotive aspects of language and as such it seems that all connotative words ,metaphoric expressions and connotation thus constitutes one of the main components of translating Holy Quran, and by virtue of its suggestive power as an emotive and expressive vehicle, it offers one of the most effective parameters according to which both the literary competence of the translator and the cultural awareness of the reader are revealed and gauged.

Khan and Hilali and Abulhaleem's translations of the Quranic metaphoric expressions are the best examples of both the extremes, where Pickthall's rendering for the Quranic metaphoric expressions seems complex being too literal, which thwarts comprehension, , and on the contrary, Khan and Hilali and Abulhaleem's dynamic rendering with abrupt turns in the form of lexical expansion has been appreciated by the majority of readers either Muslim or non Muslim. Finally, the Quranic metaphoric expressions need to be rendered figuratively or reworded into effective metaphoric and connotative with footnotes.

\section{Hypothesis Three:}

Hypothesis (3) is stated as follows:

This hypothesis arises from Research Question(3) which aims to find out the strategies are adopt by the three translators to ensure interaction between the translated texts and the Arabic socio-cultural contexts. A number of translation strategies are found to be applied by the three translators in their attempt to render the Qur'anic metaphoric expressions into English. These strategies include the following:

a. Khan and Hilali's translation of the Holy Quran is an example of an approach that attempts to be most" faithful" to the source; being text-centered. This explains their frequent use of footnotes to explicate ambiguous terms and expression. Moreover, footnotes are one of the most common strategies used by translators for explication terms and phrases that do not have an equivalent in the TL, or whose direct equivalent results in a drastic loss of meaning. Sometimes footnotes are also used to refer to other 
ayahs related to the term or expression to help explain the meaning( see the examples)

b. Pickthall does not provide his translation with footnotes or commentary to enable the readers of his translation to gain sufficient information for a proper understanding. Moreover, he does not support his translation with Hadiths and exegeses, which can help in reinforcing the elements of the suras ( see the examples )

c. Abdul-Halemm often uses footnotes in his translation. According to him $(2005, \mathrm{p} .87)$ " footnotes are meant to be minimal, and to explain allusions, references, and cultural background only when it was felt these were absolutely necessary to clarify meaning and context( see the examples).

d. Khan and Hilali and Abdul-Haleem have adopted an explanatory approach a long with transliteration (e.g. examples from 1-20).

e. Translation of the Holy Quran texts often tends to include additional statements and phrases for the purpose of explication. Addition (expansion strategy) takes more than one form and used for different purposes depending on the context and style of the translator. Abdul-Haleem uses addition strategy in his translation( see the examples)

f. Khan and Hilali as well as Abdul-Haleem sometimes uses cultural substitution strategies in their rendering and by explaining cultural items through meaning of sense in the ST, therefore, give only a literal translation which may lead to ambiguity (see the examples)

g. All the three translators sometimes use the communicative translation strategies which aim at rendering the Qur'anic euphemistic expressions into English and producing for its readers the closet effect that of the ST.All the three translators sometimes use the semantic translation strategies which aims at rendering and producing, as closely as the structures and nature of the SL, besides allowing the exact meaning of the SL message. (see the examples).

\section{CONCLUSION}

\subsection{Summary of Findings}

On the bases of the theoretical part and data analysis, the current study has come up with the following conclusions:

1. Translating Qur'anic metaphor is an even more demanding task than translating metaphor in other subjects owing to the fact that religious text, such as The Holy Quran, contains more complex connotative meanings and therefore, no universality exists in the terms used. This is in stark to contrast to the domain of science where each term and definition has a universal acceptance.

2. Translating metaphor meanings in the Quranic texts is not quite easy. This is because Qur'anic metaphor involves very subtle differences in meaning that are difficult to grasp.

3. There are various instances where cultural details are given in the Quran. These expressions are usually rendered by literal rendering or performing transliteration. The translators are often unable to analyze these cultural terms and aspects of the Holy Quran and neither are they able to find the best and closest expressions to convey the same meaning and images.

4. It is extremely difficult to translate the Qur'an literally because the Arabic terms, expressions, and lexemes often have multiple literal meanings and are often used figuratively. In addition, many forms of Arabic lexical structures contain nuances of meaning that cannot be translated into another language owing to linguistic barriers. Therefore, the translations of the Holy Quran are largely based on interpretation, paraphrasing, and explanation of the source text.

\subsection{Implications and Recommendations for Future Research}

This study and other similar studies can play a role in enhancing the translational knowledge, understanding, and performance of students. Moreover, the study can support teaching Arabic to English translations in Arab universities. Students can potentially benefit from this study in the application of the knowledge of translational techniques and strategies to holy texts such as Qur'an.

The results of the current study call for future research on analyzing the problems involving translating, collocations, euphemisms and lexical ambiguity in the Holy Quran. This future research could be applied not only to Arabic and English, but also to other languages, which are genetically unrelated. Additional research is needed to explore, metaphor in reference to two translations of the meaning of the Hadith.

\section{References}

Abdel-Haleem, M (1999). Understanding the Qur'an: Themes and Style. New York: I.B. Tauris and Co. Ltd. Abdelwali, M. (2007). The Loss in the Translation of the Qur'an. Translation Journal, 11 (2), April. Retrieved 10 June, 2010, from http://ranslationjournal.net/journal/40quran.htm.

Abdul-Raof, H. (2001). Qur'ān translation: Discourse, Texture and Exegesis. London: Routledge. Al-Suyūțī, Jalāl al-Dīn (1986). Al-Mazhar fì ulūm al-lughah al-'Arabiyah. (M. Mawlā, A. al-Jawi and M. 
Ibrāhīm, Eds.). Baurit: Al-Maktabah al- 'Asriyyah.

Al-Zamakhsharī, Abū l-Qāsim (1999). Al-Kashshāf 'an haqū 'iq ghawāmiḍ al-tanż̄l. Beirut: Dār al-Ma rifah.

Arberry, A. J. (1980). The Koran Interpreted (Vols.1-2). London: George Allen \& Unwin.

Badldinger K.(2001).Semantics Theory. Oxford: Basisl Blackwell.

Barnwell, K. (1999). Towards Acceptable Translation. Notes on Translation, 95, 19-25.

Bell, R.T. (1991). Translation and Translating: Theory and Practice. London: Longman.

Blight, R. (1976). Footnotes for Meaningful Translations of the New Testament. Journal of Translation, $1(1), 7$.

Catford, John C. (1990). A Linguistic Theory of Translation: An essay on applied linguistics, London: Oxford University Press.

Cresswell, S. (1994). Content Analysis: Concepts, Methods and Applications. Nurse Researcher, 4(3), 5-16.

Cohen, J.M. (1990). English Translators and Translations. London: Longman.

Cohen, J.M (1986)"Translation", Encyclopedia Americana, . London: Longman

Cook, G. (1991. Discourse Analysis . Oxford: Oxford University Press.

Halliday, M. A. K. (1994). An Introduction to Functional Grammar. London: Edward Arnold.

Hatim, B. \& Mason, I. (1990). Discourse and the Translator. London: Longman.

Hosni, A.M. (2004). On Translating the Qur'an: An Introductory Essay. Journal of King Saud University, 2(2), 93-134.

Jakobson, R. (1990). On Linguistic Aspects of Translation. In R. A. Brower (Ed.), On translation (pp. 232-39), Cambridge, MA: Harvard University Press.

Johnstone, B. (1991). Repetition in Arabic Discourse, Paradigms, Syntagms, and the Ecology of Language. Amsterdam: John Benjamins Publishing Company.

Kelly, L.G. (1997). The True Interpreter: A History of Translation theory and practice in the West. Oxford: B. Blackwell.

Koller, W.(2005).Equivalence in Translation. Harmondsworth: Penguin

Kussmaul, P.(1995)Training the Translator. Amsterdam: John Benjamins Publishing Company..

Laboner(2008).Semantics. London: Continuum.

Marlonr. J.(1988)Introduction to Translation. London: The Macmillan Company. Ltd.

Martin, J. R. \& Mason D. (1997). Working with Discourse: Meaning beyond the clause. London: Continuum..

Newmark, P. (1988). A Textbook of Translation. Hertfordshire: Prentice Hall.

Nida, E. (2001). Contexts in Translating. Amsterdam: John Benjamins Publishing Company.

Pickthall, M. (2001). The Meaning of the Glorious Qur'an: An explanatory translation. London: George Allen and Unwin Ltd.

Steiner, G.(1998). After Babel : Aspect of Language and Translation. Amsterdam: John Benjamins Publishing Company.

Wills, W. (1982). The science of translation. Tubingen: Narr.World book dictionary online. http://www.thefreedictionary.com.

Online Sources

http://www.thefreedictionary.com/tablets.

http://www.thefreedictionary.com.

http://www.jewishencyclopedia.com/view.jsp?artid=39\&letter=E.

http://dictionary.cambridge.org/dictionary/british/swear 2.

http://www.oxforddictionaries.com/view/entry/m_en gb0620720\#m en gb0620720.

http://www.britannica.com/EBchecked/topic/452123/perjury.

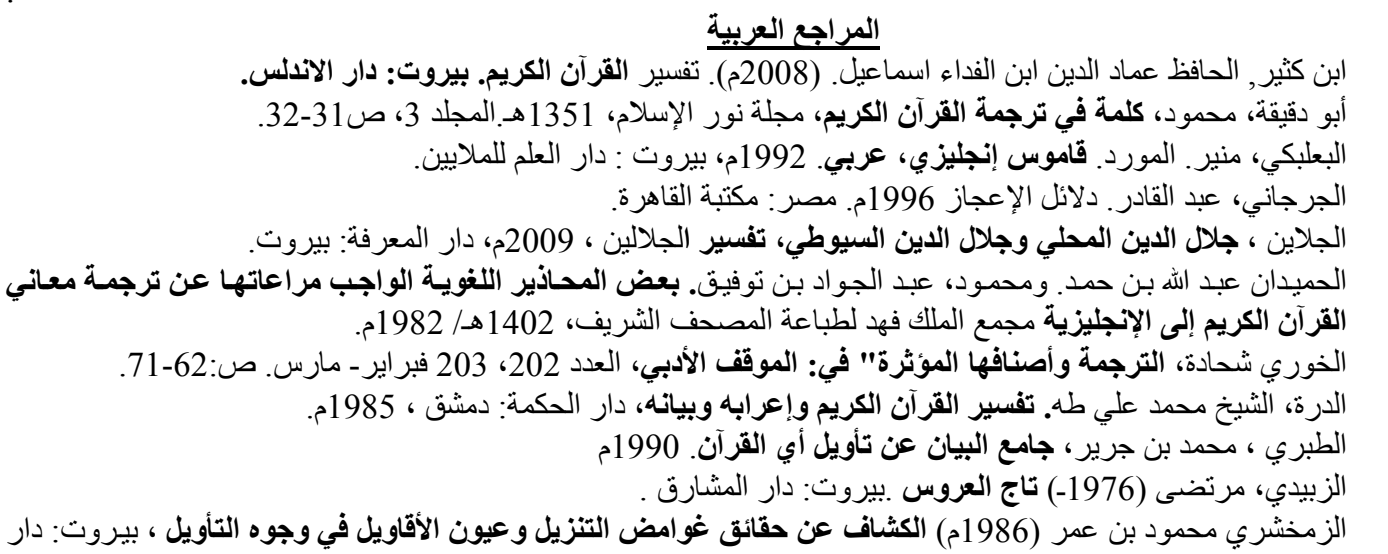




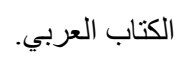

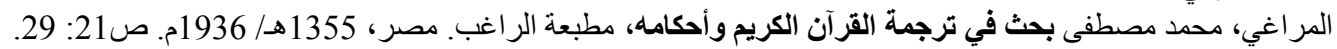
الندوي، عبد الله عباس. ترجمات معاني القرآن الكريم وتطور فهمه عند العرب" مجلة الكية دعوة الحق. العدد 174 مطابع رابطة

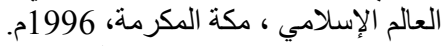

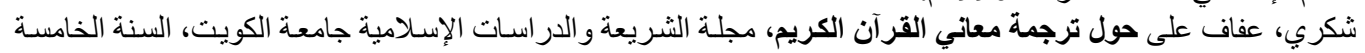

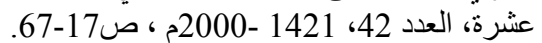
صبري، مصطفى ، مسألة ترجمة القرآن، المطبعة السلفية ، مصر : 1321 1351هـ، 1933م. عناني ، محمد، الترجمة الأبية ، بين النظرية والتطبيق ـ الثركة المصرية العالمية للنشر ، لونجمان. مصر ، 1997م. 